\title{
PROBLEMATIKA ANAK TUNARUNGU DAN CARA MENGATASINYA
}

\author{
Fifi Nofiaturrahmah \\ IAIN Kudus, Indonesia \\ fifinofiaturrahmah@gmail.com
}

\begin{abstract}
Abstrak
Anak Tunarungu menunjukkan kesulitan mendengar dari kategori ringan sampai berat, digolongkan ke dalam kurang dengar dan tuli. Tunarungu adalah orang yang kehilangan kemampuan mendengar sehingga menghambat proses informasi bahasa melalui pendengarannya, baik memakai ataupun tidak memakai alat bantu dengar dimana batas pendengaran yang dimilikinya cukup memungkinkan keberhasilan proses informasi bahasa melalui pendengaran. Tulisan ini dalam bentuk kualitatif tentang anak tunarungu dan solusi yang dimungkinkan untuk mengatasi kebutuhan khusus. diantaranya : melalui media pembelajaran dengan menunjukkan foto-foto, video, kartu huruf, kartu kalimat, anatomi telinga, miniatur benda, finger elphabet, model telinga, torso setengah badan, puzzle buah-buahan, puzzle binatang, puzzle konstruksi, silinder, model geometri, menara segitiga, menara gelang, menara segi empat, atlas, globe, peta dinding, miniatur rumah adat. Anak tunarungu memerlukan media belajar berupa alat peraga untuk memperkaya perbendaharaan bahasa. Alat-alat peraga itu antara lain miniatur binatang-binatang, miniatur manusia, gambar-gambar yang relevan, buku perpustakaan yang bergambar, dan alat-alat permainan anak.
\end{abstract}

Kata Kunci : Pendengaran, Tunarungu, solusi anak tunarungu.

\begin{abstract}
Deaf children show difficulty hearing from mild to severe categories, classified into hearing and deafness. Deaf is a person who loses the ability to hear so that it inhibits the process of language information through hearing, whether using or not using a hearing aid where the hearing limit is enough to allow the success of the language information process through hearing. This paper is in the form of qualitative on deaf children and possible solutions to addressing special needs. including: through learning media by showing photographs, videos, letter cards, sentence cards, ear anatomy, miniature objects, finger elphabet, ear models, half body torso, fruit puzzles, animal puzzles, construction puzzles, cylinders, geometry models, triangular tower, bracelet tower, rectangular tower, atlas, globe, wall map, miniature traditional house. Deaf children need learning media in the form of teaching aids to enrich the language treasury. The props included miniatures of animals, human miniatures, relevant images, illustrated library books, and children's game tools.
\end{abstract}

Keywords: Hearing; Deaf; solution for deaf children. 


\section{A. Pendahuluan}

Anak tunarungu memiliki hambatan dalam pendengaran akibatnya individu tunarungu memiliki hambatan dalam berbicara sehingga mereka biasa disebut tunawicara. Cara berkomunikasi seseorang yang menyandang tuna rungu dengan individu lain yaitu menggunakan bahasa isyarat, untuk abjad jari telah dipatenkan secara internasional sedangkan untuk isyarat bahasa berbeda-beda di setiap negara.

Intelegensi anak tunarungu tidak berbeda dengan anak normal yaitu tinggi, rata-rata dan rendah. Pada umumnya anak tunarungu memiliki entelegensi normal dan rata-rata. Prestasi anak tunarungu seringkali lebih rendah daripada prestasi anak normal karena dipengaruhi oleh kemampuan anak tunarungu dalam mengerti pelajaran yang diverbalkan. Namun untuk pelajaran yang tidak diverbalkan, anak tunarungu memiliki perkembangan yang sama cepatnya dengan anak normal. Prestasi anak tunarungu yang rendah bukan disebabkan karena intelegensinya rendah namun karena anak tunarungu tidak dapat memaksimalkan intelegensi yang dimiliki. Aspek intelegensi yang bersumber pada verbal seringkali rendah, namun aspek intelegensi yang bersumber pada penglihatan dan motorik akan berkembang dengan cepat.

Berdasarkan hasil wawancara dengan bu Anastasia selaku wali kelas 1 di SLBN Kaliwungu Kudus, beliau memberitahukan bahwa di kelas yang beliau ajar ada 2 jenis anak dalam satu kelas yakni: tuna rungu dan tuna grahita. Menurut penuturan beliau dalam mengahadapi pembelajaran di kelas bu Anastasia memiliki strategi berbeda dalam mengani setiap anak dalam satu kelas dan itu disesuaikan dengan tuna yang dialaminya (Hasil wawancara dengan Anastasia Rustiani, 7 Januari 2019). Dalam tulisan ini akan membahas tentang apa itu tunarungu, faktor-faktor yang menyebabkan seseorang dikatakan tunarungu, karakteristik anak-anak tunarungu, kebutuhan anak tunarungu, dan solusi anak tunarungu agar bisa seperti anak normal pada umumnya.

Jenis penelitian dapat dilihat dari berbagai sisi, yaitu sisi tujuan, kegunaan, sumber data, pendekatan, dan teknik analisis data yang digunakan. Jika dilihat dari sisi tujuan penelitian yang dilakukan, penelitian ini termasuk penelitian diskriptif. Penelitian diskriptif adalah penelitian yang bertujuan untuk menggambarkan pelakasanaan pendidikan karakter di pesantren. Jika dilihat dari sisi kegunaan penelitian, penelitian ini termasuk penelitian murni (applied research). Penelitian 
terapan adalah penelitian yang hati-hati, sistematik, dan terus menerus dilakukan terhadap suatu masalah dengan tujuan digunakan untuk keperluan tertentu (Moh. Nizar, 1988 : 29-30). Jika dilihat dari sumber datanya, maka penelitian ini termasuk penelitian lapangan (field research). Jika dilihat dari sisi pendekatan yang digunakan, maka penelitian ini termasuk penelitian fenomenologi. Adapun jika dilihat dari sisi tehnik analisis data yang digunakan, maka penelitian ini termasuk penelitian kualitatif. Penelitian kualitatif merupakan penelitian dimana peneliti meneliti informan sebagai subyek penelitian dalam lingkungan hidup keseharian (Muhammad Idrus, 2009 : 23). Penelitian kualitatif memiliki beberapa karakteristik yaitu: pertama, berlangsung dalam latar ilmiah. Kedua, peneliti adalah instrument atau alat pengumpul data yang utama. Ketiga, analisis datanya dilakukan secara induktif (Lexy J. Moleong, $1989: 3$ ).

\section{B. Pembahasan}

\section{Pengertian Tunarungu}

Menurut Soewito dalam buku Ortho paedagogik Tunarungu adalah : "Seseorang yang mengalami ketulian berat sampai total, yang tidak dapat menangkap tuturkata tanpa membaca bibir lawan bicaranya". Anak tunarungu adalah anak yang mengalami kehilangan kemampuan mendengar baik itu sebagian atau seluruhnya yang diakibatkan kerusakan fungsi pendengaran baik sebagian atau seluruhnya sehingga membawa dampak kompleks terhadap kehidupannya.

Anak tunarungu merupakan anak yang mempunyai gangguan pada pendengarannya sehingga tidak dapat mendengar bunyi dengan sempurna atau bahkan tidak dapat mendengar sama sekali, tetapi dipercayai bahwa tidak ada satupun manusia yang tidak bisa mendengar sama sekali. Walaupun sangat sedikit, masih ada sisa-sisa pendengaran yang masih bisa dioptimalkan pada anak tunarungu tersebut. Berkenaan dengan tunarungu, terutama tentang pengertian tunarungu terdapat beberapa pengertian sesuai dengan pandangan masing-masing. Menurut Andreas Dwidjosumarto mengemukakan bahwa seseorang yang tidak atau kurang mampu mendengar suara dikatakan tunarungu. Ketunarunguan dibedakan menjadi dua kategori, yaitu tuli (deaf) atau kurang dengar (hard of hearing) (Laila, 2013: 10).

Murni Winarsih mengemukakan bahwa tunarungu adalah suatu istilah umum yang menunjukkan kesulitan mendengar dari yang ringan sampai berat, digolongkan ke dalam tuli dan kurang dengar. Orang tuli adalah yang kehilangan kemampuan mendengar sehingga menghambat proses informasi bahasa melalui pendengaran, baik 
memakai ataupun tidak memakai alat bantu dengar dimana batas pendengaran yang dimilikinya cukup memungkinkan keberhasilan proses informasi bahasa melalui pendengaran. Tin Suharmini mengemukakan tunarungu dapat diartikan sebagai keadaan dari individu yang mengalami kerusakan pada indera pendengaran sehingga menyebabkan tidak bisa menangkap berbagai rangsang suara, atau rangsang lain melalui pendengaran (Laila, $2013: 10$ ).

Beberapa pengertian dan definisi tunarungu di atas merupakan definisi yang termasuk kompleks, sehingga dapat disimpulkan bahwa anak tunarungu adalah anak yang memiliki gangguan dalam pendengarannya, baik secara keseluruhan ataupun masih memiliki sisa pendengaran. Meskipun anak tunarungu sudah diberikan alat bantu dengar, tetap saja anak tunarungu masih memerlukan pelayanan pendidikan khusus.

\section{Faktor Penyebab Anak Tunarungu}

Kehilangan pendengaran bisa disebabkan oleh faktor genetik, infeksi pada ibu seperti cacar air selama kehamilan, komplikasi ketika melahirkan, atau penyakit awal masa kanak-kanak seperti gondok atau cacar air. Banyak anak sekarang ini dilindungi dari kehilangan pendengaran dengan vaksinasi seperti untuk mencegah infeksi. Tanda-tanda masalah pendengaran adalah mengarahkan salah satu telinga ke pembicara, menggunakan salah satu telinga dalam percakapan, atau tidak memahami percakapan ketika wajah pembicara tidak dapat dilihat indikasi lain adalah tidak mengikuti arahan, sering kali meminta orang untuk mengulang apa yang mereka katakan, salah mengucapkan kata atau nama baru, atau tidak mau berpartisipasi dalam diskusi kelas (Anita, 2004 : 608).

Sebab-sebab kelainan pendengaran atau tunarungu juga dapat terjadi sebelum anak dilahirkan, atau sesudah anak dilahirkan. Menurut Sardjono mengemukakan bahwa faktor penyebab ketunarunguan dapat dibagi dalam:

a. Faktor-faktor sebelum anak dilahirkan (pre natal)

1) Faktor keturunan Cacar air,

2) Campak (Rubella, Gueman measles)

3) Terjadi toxaemia (keracunan darah)

4) Penggunaan pilkina atau obat-obatan dalam jumlah besar

5) Kekurangan oksigen (anoxia)

6) Kelainan organ pendengaran sejak lahir 
b. Faktor-faktor saat anak dilahirkan (natal)

c. Faktor Rhesus (Rh) ibu dan anak yang sejenis

1) Anak lahir pre mature

2) Anak lahir menggunakan forcep (alat bantu tang)

3) Proses kelahiran yang terlalu lama

d. Faktor-faktor sesudah anak dilahirkan (post natal)

1) Infeksi

2) Meningitis (peradangan selaput otak)

3) Tunarungu perseptif yang bersifat keturunan

4) Otitismedia yang kronis

5) Terjadi infeksi pada alat-alat pernafasan.

Peneliti menyimpulkan bahwa faktor penyebab terjadinya tuna rungu wicara yaitu pre natal (keturunan), natal (bawaan dari pihak ibu), post natal (otitis media).

\section{Karakteristik Anak Tunarungu}

Tunarungu adalah istilah yang menunjuk pada kondisi ketidakfungsian organ pendengaran atau telinga seseorang anak. Kondisi ini menyebabkan mereka memiliki karakteristik yang khas, berbeda dari anak normal pada umumnya. Beberapa karakteristik anak tunarungu diantaranya adalah:

a. Segi Fisik

1) Cara berjalannya kaku dan agak membungkuk akibat terjadinya permasalahan pada organ keseimbangan di telinga. Itulah sebabnya anak-anak tunarungu mengalami kekurangan keseimbangan dalam aktivitas fisiknya.

2) Pernapasannya pendek dan tidak teratur. Anak-anak tunarungu tidak pernah mendengarkan suara-suara dalam kehidupan sehari-hari. Bagaimana bersuara atau mengucapkan kata-kata dengan intonasi yang baik, sehingga mereka juga tidak terbiasa mengatur pernapasannya dengan baik, khususnya dalam berbicara.

3) Cara melihatnya agak beringas. Penglihatan merupakan salah satu indra yang paling dominan bagi anak-anak penyandang tunarungu karena sebagian besar pengalamannya diperoleh melalui penglihatan. Oleh karena itu anak-anak tunarungu juga dikenal sebagai anak visual sehingga cara melihatnya selalu menunjukkan keingintahuan yang besar dan terlihat beringas.

b. Segi Bahasa

1) Kosa kata yang dimiliki tidak banyak. 
2) Sulit mengartikan kata-kata yang mengandung ungkapan atau idiomatik.

3) Tata bahasanya kurang teratur

c. Intelektual

1) Kemampuan intelektualnya normal. Pada dasarnya anak-anak tunarungu tidak mengalami permasalahan dalam segi intelektual. Namun akibat keterbatasan dalam berkomunikasi dan berbahasa, perkembangan intelektualnya menjadi lamban

2) Perkembangan akademiknya lamban akibat keterbatasan bahasa. Sering terjadinya keterlambanan dalam perkembangan intelektualnya akibat adanya hambatan dalam berkomunikasi, dalam segi akademik anak tunarungu juga mengalami keterlambatan

d. Sosial-Emosional

1) Sering merasa curiga dan berprasangka. Sikap seperti ini terjadi akibat adanya kelainan fungsi pendengarannya. Mereka tidak dapat memahami apa yang dibicarakan orang lain sehingga anak-anak tunarungu menjadi mudah merasa curiga.

2) Sering bersikap agresif. Anak-anak tunarungu bersikap agresif karena mereka merasa tidak bisa mengartikan apa yang dikatakan orang lain.

Anak tunarungu juga mengalami kelainan dalam fungsi pendengarannya sehingga menimbulkan hambatan dalam berkomunikasi dengan orang yang bisa mendengar. Hal ini tentu saja bisa menghambat pengembangan potensi yang dimilikinya. Oleh karena itu, dalam menjalani kehidupan sehari-hari, anak tunarungu memiliki hak sebagai berikut (Laili, 2013:10) :

a) Hak mendapatkan perlindungan sesuai dengan isi Pembukaan UUD 1945 alinea ke-4

b) Hak untuk mendapatkan pendidikan dan pengajaran

c) Anak tunarungu sebagai warga negara Republik Indonesia mempunyai kedudukan yang sama baik dalam hukum maupun dalam pemerintahan, jadi walaupun mereka itu mempunyai kelainan dalam indera pendengarannya, tetapi mereka berhak mendapat kedudukan yang sama seperti halnya anak yang lain dan wajib menjunjung hukum dan pemerintahan

d) Anak tunarungu berhak mendapat pekerjaan dan penghidupan yang layak seperti halnya anak-anak yang normal 
Adapun kewajiban anak tunarungu sesuai dengan kemampuan yang ada padanya adalah sebagai berikut:

1) Kewajiban anak tunarungu akan dirinya sendiri, yang meliputi:

a) Mencintai dirinya

b) Menerima keadaan dirinya

c) Menyadari akan nasibnya

d) Memelihara kesehatan dan kebersihan dirinya

e) Berusaha mengembangkan kemampuannya

2) Kewajiban bersekolah/belajar

a) Taat dan patuh pada peraturan sekolah

b) Mengikuti seluruh kegiatan yang diselenggarakan sekolah

c) Menghormati kepala sekolah, guru, dan mereka yang dianggap lebih tua dari padanya dan sepatutnya untuk dihormati

d) Berbuat baik terhadap teman-teman sekelas dan teman-teman satu sekolah

e) Menjaga citra sekolah

3) Kewajiban dalam lingkungan keluarga

a) Patuh dan taat pada orang tua

b) Berlaku baik pada saudara

c) Mengikuti jejak anggota keluarga

d) Ikut ambil bagian dalam tugas sebagai anggota keluarga

4) Kewajiban dalam lingkungan masyarakat

e) Menyesuaikan diri dengan lingkungan masyarakat, sesuai dengan kemampuan yang ada padanya

f) Menghormati anggota masyarakat

g) Turut ambil bagian dalam melaksanakan tugas sesuai dengan kemampuan yang ada padanya

h) Menaati peraturan masyarakat yang telah ditetapkan (Laili : 30-33, 2013).

i) Menurut Permanarian Somad dan Tati Hernawati mendeskripsikan karakteristik ketunarunguan dilihat dari segi: intelegensi, bahasa dan bicara, emosi, dan sosial.

a. Karakteristik dari segi intelegensi

Intelegensi anak tunarungu tidak berbeda dengan anak normal yaitu tinggi, rata-rata dan rendah. Pada umumnya anak tunarungu memiliki intelegensi normal dan rata-rata. Prestasi anak tunarungu seringkali lebih rendah daripada prestasi 
anak normal karena dipengaruhi oleh kemampuan anak tunarungu dalam mengerti pelajaran yang diverbalkan. Namun untuk pelajaran yang tidak diverbalkan, anak tunarungu memiliki perkembangan yang sama cepatnya dengan anak normal. Prestasi anak tunarungu yang rendah bukan disebabkan karena intelegensinya rendah namun karena anak tunarungu tidak dapat memaksimalkan intelegensi yang dimiliki. Aspek intelegensi yang bersumber pada verbal seringkali rendah, namun aspek intelegensi yang bersumber pada penglihatan dan motorik akan berkembang dengan cepat.

b. Karakteristik dari segi bahasa dan bicara

Kemampuan anak tunarungu dalam berbahasa dan berbicara berbeda dengan anak normal pada umumnya karena kemampuan tersebut sangat erat kaitannya dengan kemampuan mendengar. Karena anak tunarungu tidak bisa mendengar bahasa, maka anak tunarungu mengalami hambatan dalam berkomunikasi. Bahasa merupakan alat dan sarana utama seseorang dalam berkomunikasi. Alat komunikasi terdiri dan membaca, menulis dan berbicara, sehingga anak tunarungu akan tertinggal dalam tiga aspek penting ini. Anak tunarungu memerlukan penanganan khusus dan lingkungan berbahasa intensif yang dapat meningkatkan kemampuan berbahasanya. Kemampuan berbicara anak tunarungu juga dipengaruhi oleh kemampuan berbahasa yang dimiliki oleh anak tunarungu. Kemampuan berbicara pada anak tunarungu akan berkembang dengan sendirinya namun memerlukan upaya terus menerus serta latihan dan bimbingan secara profesional. Dengan cara yang demikian banyak dari mereka yang belum bisa berbicara seperti anak normal baik dari segi suara, irama dan tekanan suara terdengar monoton berbeda dengan anak normal.

c. Karakteristik dari segi emosi dan sosial

Ketunarunguan dapat menyebabkan keterasingan dengan lingkungan. Keterasingan tersebut akan menimbulkan beberapa efek negatif seperti: egosentrisme yang melebihi anak normal, mempunyai perasaan takut akan lingkungan yang lebih luas, ketergantungan terhadap orang lain, perhatian mereka lebih sukar dialihkan, umumnya memiliki sifat yang polos dan tanpa banyak masalah, dan lebih mudah marah dan cepat tersinggung.

1) Egosentrisme yang melebihi anak normal

Sifat ini disebabkan oleh anak tunarungu memiliki dunia yang kecil akibat interaksi dengan lingkungan sekitar yang sempit. Karena mengalami gangguan 
dalam pendengaran, anak tunarungu hanya melihat dunia sekitar dengan penglihatan. Penglihatan hanya melihat apa yang di depannya saja, sedangkan pendengaran dapat mendengar sekeliling lingkungan. Karena anak tunarungu mempelajari sekitarnya dengan menggunakan penglihatannya, maka akan timbul sifat ingin tahu yang besar, seolah-olah mereka haus untuk melihat, dan hal itu semakin membesarkan egosentrismenya.

2) Mempunyai perasaan takut akan lingkungan yang lebih luas

Perasaan takut yang menghinggapi anak tunarungu seringkali disebabkan oleh kurangnya penguasaan terhadap lingkungan yang berhubungan dengan kemampuan berbahasanya yang rendah. Keadaan menjadi tidak jelas karena anak tunarungu tidak mampu menyatukan dan menguasai situasi yang baik.

3) Ketergantungan terhadap orang lain

Sikap ketergantungan terhadap orang lain atau terhadap apa yang sudah dikenalnya dengan baik, merupakan gambaran bahwa mereka sudah putus asa dan selalu mencari bantuan serta bersandar pada orang lain.

4) Perhatian mereka lebih sukar dialihkan

Sempitnya kemampuan berbahasa pada anak tunarungu menyebabkan sempitnya alam fikirannya.Alam fikirannya selamanya terpaku pada hal-hal yang konkret. Jika sudah berkonsentrasi kepada suatu hal, maka anak tunarungu akan sulit dialihkan perhatiannya ke hal-hal lain yang belum dimengerti atau belum dialaminya. Anak tunarungu lebih miskin akan fantasi.

5) Umumnya memiliki sifat yang polos, sederhana dan tanpa banyak masalah

Anak tunarungu tidak bisa mengekspresikan perasaannya dengan baik. Anak tunarungu akan jujur dan apa adanya dalam mengungkapkan perasaannya. Perasaan anak tunarungu biasanya dalam keadaan ekstrim tanpa banyak nuansa dan cepat tersinggung karena banyak merasakan kekecewaan akibat tidak bisa dengan mudah mengekspresikan perasaannya, anak tunarungu akan mengungkapkannya dengan kemarahan. Semakin luas bahasa yang mereka miliki semakin mudah mereka mengerti perkataan orang lain, namun semakin sempit bahasa yang mereka miliki akan semakin sulit untuk mengerti perkataan orang lain sehingga anak tunarungu mengungkapkannya dengan kejengkelan dan kemarahan. 
Pembelajaran untuk anak tuna rungu. Menurut informasi yang diberikan dari bu Anastasia, anak tura rungu memiliki keterbatasan dalam pendengarannya. Sehingga anak tersebut dalam berkomunikasi harus menggunakan bahasa isyarat.Disini anak tuna rungu mendapatkan bina wicara agar anak dapat berkomunikasi dengan baik. Mengenai anak tuna rungu itu sendiri dalam kelas 1 ini dibedakan ada 2 yaitu: tuna rungu ringan dan tuna rungu berat. Biasanya bu Anastasia meggunakan bahasa isyarat saat berkomunikasi dengan anak tuna rungu, dimana bahasa isyarat ini beliau masih menggunakan bahasa isyarat lokal, belum menggunakan bahasa isyarat yang internasional yang biasa digunakan di Negara-negara luar. (Hasil wawancara dengan Anastasia Rustiani, 7 Januari 2019).

Anak tunarungu bisa berkonsentrasi dan cepat memahami kejadian yang sudah dialaminya dan bersifat konkret bukan hanya hal yang diverbalkan. Anak tunarungu membutuhkan metode yang tepat untuk meningkatkan kemampuan berbahasanya yaitu metode yang dapat menampilkan kekonkretan sesuai dengan apa yang sudah dialaminya. Metode pembelajaran untuk anak tunarungu haruslah yang kaya akan bahasan konkret dan tidak membiarkan anak untuk berfantasi mengenai hal yang belum diketahui.

\section{Kebutuhan Anak Tunarungu}

Anak tunarungu seperti halnya anak normal pada umumnya, mempunyai kebutuhan-kebutuhan utama yang dikemukakan oleh Salim sebagaiberikut:

a. Kebutuhan akan keteraturan yang bersifat biologis seperti kebutuhan makan, minum, tidur, bermain, dan sebagainya.

b. Kebutuhan menjadi bagian yang tak terpisahkan dalam keluarga. Anak tunarungu membutuhkan perlakuan yang wajar, ikut serta dalam suka dan duka dan kesibukan seperti halnya anggota keluarga yang lain.

c. Kebutuhan akan keberhasilan dalam suatu kegiatan baik secara individual maupun secara kolektif. Anak tunarungu menghendaki segala usaha mencapai hasil yang memuaskan baik untuk dirinya sendiri maupun untuk orang lain, meskipun anak tunarungu harusmengalami berbagai hambatan dan kesukaran sebagai akibat ketunaannya.

d. Kebutuhan akan aktivitas, yaitu kebutuhan ikut terlibat dalam kegiatan keluarga maupun dalam lingkungan yang lebih luas lagi. Sebagaimana halnya pada anak 
normal lainnya, anak tunarungu pun ingin melibatkan diri dalam permainan dengan teman sebayanya.

e. Kebutuhan akan kebebasan, yakni ia membutuhkan kebebasan untuk berbuat, berinisiatif, bebas untuk bertanggung jawab atas perbuatannya sendiri. anak tunarungu tidak ingin selalu terikat oleh orang lain. Kebebasan yang anak tunarungu butuhkan bukan kebebasan mutlak, melainkan kebebasan dengan batas-batas tertentu.

f. Kebutuhan akan kesehatan, yakni merupakan kebutuhan wajar anak yang sedang tumbuh. Anak tunarungu memerlukan tubuh yang sehat, kuat serta mampu menjaga diri dari berbagai gangguan penyakit.

g. Kebutuhan untuk berekspresi, yaitu kebutuhan untuk mengemukakan pendapat yang dapat dipahami oleh orang lain. anak tunarungu memerlukan bimbingan komunikasi yang wajar untuk dapat mengemukakan pikiran, perasaan, serta kehendaknya kepada orang lain. Kebutuhan berekspresi ini bukan hanya yang berhubungan dengan masalah komunikasi, melainkan juga bentuk-bentuk ekspresi lain seperti menggambar, bermain peran, melakukan kegiatan atau pekerjaan lain yang dapat mewakili curahan isi hatinya Memperhatikan kebutuhan-kebutuhan anak tunarungu di atas, dapat disebutkan bahwa pada prinsipnya kebutuhan-kebutuhan mendasar anak tunarungu itu tidak jauh berbeda dengan kebutuhan-kebutuhan anak normal lainnya. Baik karakteristik maupun kebutuhan-kebutuhan anak tunarungu, kedua aspek tersebut merupakan hal yang harus dipahami betul oleh guru terutama untuk kepentingan memberikan pengajaran kepada mereka.

Menurut Depdiknas ada beberapa hal yang terlebih dahulu harus dipahami secara seksama oleh guru yang bertalian dengan kegiatan pembelajaran, yaitu:

1) Anak tunarungu sebagai siswa dengan segala karakteristiknya yang terus berusaha mengembangkan dirinya seoptimal mungkin melalui berbagai kegiatan belajar. Guna mencapai tujuan sesuai dengan tahapan perkembangan yang dijalaninya.

2) Tujuan, yaitu akhir dari yang diharapkan setelah adanya kegiatan Pembelajaran. Tujuan merupakan seperangkat tugas, tuntutan atau kebutuhan yang harus dipenuhi atau sistem nilai yang harus nampak dalam sistem perilaku dan merupakan karakteristik kepribadian anaktunarungu yang diterjemahkan ke dalam berbagai bentuk kegiatan yang berencana dan dapat dievaluasi (diukur). 
3) Guru, yaitu orang dewasa yang karena jabatannya secara formal selalu mengusahakan terciptanya situasi yang tepat (mengajar), sehingga memungkinkan tercapainya tujuan Pembelajaran yang diharapkan. Terjadinya proses pengalaman belajar (learning experiences) dengan menggunakan strategi belajar mengajar (teaching-learning strategic) yang tepat.

\section{Solusi Anak Tunarungu Bisa Seperti Anak Normal}

Salah satu solusi untuk anak Tunarungu adalah Sekolah inklusi. Sekolah inklusi merupakan perkembangan baru dari pendidikan terpadu. Pada sekolah inklusi setiap anak sesuai dengan kebutuhan khususnya, semua diusahakan dapat dilayani secara optimal dengan melakukan berbagai modifikasi dan penyesuaian, mulai dari kurikulum, sarana prasarana, tenaga pendidik dan kependidikan, sistem pembelajaran sampai pada sistem penilaiannya (Nenden Ineu Herawati, 3).

Sekolah inklusi adalah sekolah biasa/reguler yang menyelenggarakan pendidikan inklusi dengan mengakomodasi semua peserta didik baik anak normal maupun anak berkebutuhan khusus yaitu anak yang menyandang kelainan fisik, intelektual, sosial, emosi, mental cerdas, berbakat istimewa, suku terasing, korban bencana alam, bencana social, mempunyai perbedaan warna kulit, gender, suku bangsa, ras, bahasa, budaya, agama, tempat tinggal, kelompok politik, anak kembar, yatim, yatim piatu, anak terlantar, anak tuna wisma, anak terbuang, anak terlibat sistem pengadilan remaja, anak terkena daerah konflik senjata, anak pengemis, anak terkena dampak narkoba, HIV/AIDS (ODHA), anak nomaden dan lain-lain sesuai kemampuan dan kebutuhannya (Alimin, Z dan Permanarian : 2005).

Anak tunarungu memiliki hambatan dalam pendengaran, individu tunarungu memiliki hambatan dalam berbicara sehingga mereka biasa disebut tunawicara. Cara berkomunikasi dengan individu menggunakan bahasa isyarat, untuk abjad jari telah dipatenkan secara internasional sedangkan untuk isyarat bahasa berbeda-beda di setiap negara. Saat ini di beberapa sekolah sedang dikembangkan komunikasi total yaitu cara berkomunikasi dengan melibatkan bahasa verbal, bahasa isyarat, dan bahasa tubuh. Individu tunarungu cenderung kesulitan dalam memahami konsep dari sesuatu yang abstak (Harizal Mudjito : 2012, 27).

Mengajar anak tunarungu pasti berbeda dengan anak normal, maka dibutuhkan media untuk membantu anak tunarungu. Pengertian media dalam proses belajar mengajar cenderung diartikan sebagai alat-alat grafis, photografis, atau elektronis untuk menangkap, memproses, dan menyususn kembali informasi visual atau verbal. 
AECT (Association of Education and Communication Technology) memberi batasan tentang media sebagai segala bentuk dan saluran yang digunakan untuk menyampaikan pesan atau informasi. Selain sebagai sistem penyampai atau pengantar, media yang sering diganti dengan mediator menurut Fleming adalah penyebab atau alat yang turut campur tangan dalam dua pihak dan mendamaikannya (Ahmad Rohani, $1997: 3$ )

Menurut pendapat yang lain media adalah alat saluran komunikasi. Kata media berasal dari bahasa latin, yang merupakan bentuk jamak dari kata medium yang secara harfiyah berarti perantar, yaitu perantara antara sumber pesan (a source) dengan penerima pesan (a receifer). Beberapa halyang termasuk kedalam media adalah film, televisi, diagram, media cetak, komputer, instruktur, dan lain sebagainya. Contoh beberapa media tersebut dapat dijadikan sebagai media pengajaran jika dapat membawa pesan-pesan dalam rangka mencapai tujuan pembelajaran (Dina Indriana, 2011: 13).

Sugiarto menegaskan bahwa media pembelajaran adalah segala sesuatu yang digunakan orang utnuk menyampaikan pesan pembelajaran. Media pembelajaran yang baik harus memenuhi beberapa syarat, yaitu meningkatkan motivasi dan merangsang siswa untuk belajar, media dapat menjadikan siswa aktif dalam memberikan tanggapan, umpan balik dan mendorong siswa melakukan praktik yang benar (Tatang S, 2015: 54).

Solusi cara mengajar anak dengan pendengaran terganggu (tunarungu) yaitu dapat melalui media pembelajaran dengan menunjukkan foto-foto, video, kartu huruf, kartu kalimat, anatomi telinga, miniatur benda, finger elphabet, model telinga, torso setengah badan, puzzle buah-buahan, puzzle binatang, puzzle konstruksi, silinder, model geometri, menara segitiga, menara gelang, menara segi empat, atlas, globe, peta dinding, miniatur rumah adat. Anak tunarungu yang memiliki keterbatasan dalam berbicara dan mendengar, memerlukan media pembelajaran yang berupa media visual. Adapun cara menerangkannya dengan bahasa bibir/gerak bibir. Media pembelajaran yang dapat digunakan untuk anak tunarungu adalah:

a. Media stimulasi visual

1) Cermin artikulasi

2) Benda asli maupun tiruan

3) Gambar

4) Pias kata 
5) Gambar disertai tulisan

b. Media stimulasi auditoris

1) Speech trainer, yang merupakan alat elektronik untuk melatih bicara anak dengan hambatan sensori pendengaran

2) Alat musik, seperti: drum, gong, suling, piano/organ/harmonika, rebana, terompet dan sebagainya

3) Tape recorder

4) Berbagai sunber suara lainnya, antara lain:

a) Suara alam: angin menderu, gemercik air hujan, suara petir

b) Suara binatang: kicauan burung, gonggongan anjing, auman harimau, ringkikan kuda.

c) Suara yang dibuat manusia: tertawa, batuk, tepukan tangan, percakapan, bel, lonceng, peluit

d) Sound system alat untuk memperkeras suara

e) Media dengan sistem amplifikasi pendengaran, antara lain ABM, Cochlear Implant, dan loop system.

Dari paparan diatas, bisa dikatakan bahwa anak tunarungu memerlukan media belajar berupa alat peraga untuk memperkaya perbendaharaan bahasa. Alat-alat peraga itu antara lain miniatur binatang-binatang, miniatur manusia, gambar-gambar yang relevan, buku perpustakaan yang bergambar, dan alat-alat permainan anak (Laili S. Cahya, 2013 : 50-52).

\section{Simpulan}

Berdasarkan karakteristik anak tunarungu dari beberapa aspek yang sudah dibahas diatas, maka dapat disimpulkan bahwa sebagai dampak dari ketunarunguannya tersebut hal yang menjadi perhatian adalah kemampuan berkomunikasi anak tunarungu yang rendah. Intelegensi anak tunarungu umumnya berada pada tingkatan rata-rata atau bahkan tinggi, namun prestasi anak tunarungu terkadang lebih rendah karena pengaruh kemampuan berbahasanya yang rendah. Maka dalam pembelajaran di sekolah anak tunarungu harus mendapatkan penanganan dengan menggunakan metode yang sesuai dengan karakteristik yang dimiliki. 


\section{DAFTAR PUSTAKA}

Alimin, Z dan Permanarian. 2005. Reorientasi Pemahaman Konsep Special Education ke Konsep Needs Education dan Implikasinya Layanan Pendidikan. Bandung Jassi Astiti.

Cahya, Laili S. 2013. Buku Anak Untuk ABK, Yogyakarta: Familia.

Idrus, Muhammad. 2009, Metode Penelitian Ilmu Sosial, Jakarta: Erlangga.

Indriana, Dina. 2011. Ragam Alat Bantu Media Pengajaran, DIVA Press, Yogyakarta.

Moleong, Lexy J. 1989, Metodologi Penelitian Kualitatif, Bandung : Remaja Rosda Karya.

Mudjito, Harizal, Elfindri. 2012. Pendidikan Inklusif, Jakarta: Baduose Media.

Nenden Ineu Herawati, Pendidikan Inklusif dalam jurnal http://ejournal.upi.edu/index.php/eduhumaniora/article/view/2755/1795.

Nizar, Moh. 1988, Metode Penelitian, Jakarta: Ghalia Indonesia.

Rohani, Ahmad. 1997. Media Intruksional Edukatif, PT Rineka Cipta, Jakarta.

S, Tatang. 2015. Manajemen Pendidikan Berbasis Sekolah, Pustaka Setia, Bandung.

Woolfolk, Anita E. 2004. Mendidik Anak-Anak Bermasalah, Depok: Inisiasi Press. 